\title{
BLEBERAN TOURIST VILLAGE OF GUNUNG KIDUL: COMPONENT ANALYSIS OF ITS ATTRACTION, PRODUCT, MANAGEMENT AND MARKETING
}

\author{
Marsono. Universitas Gadjah Mada \\ marsono@ugm.ac.id
}

\begin{abstract}
The need to live naturally with the principal of 'going back to nature' has resulted in development of new tourist attraction: the tourist village. Village potentials such as varied natural attractions, friendly local people, unspoiled natural setting and fresh air are among attractions for the tourists. This research is aimed primarily at revealing tourist attraction elements of the products, the management, the product itself and its marketing in Bleberan Tourist Village of Playen, Gunung Kidul Regency, Yogyakarta Special Region. The primary data cover all activities from its launching in 2009 to the end of 2015, in which its development could be seen clearly. The theoretical approach applied in this research is tourist attraction component theory on the product, its management and marketing.
\end{abstract}

Key words: tourism product, attraction components, management and marketing.

\section{Introduction}

Among other four regencies in Yogyakarta Special Region, Gunung Kidul Regency is experiencing notable increase in tourist visits (Keadulatan Rakyat, January 14, 2015:3). This is in part from the visits to Bleberan tourist village. Below is the table summarizing the increase of tourist visits to Gunung Kidul:

Number of Visits and Direct Income from Retribution in Gunung Kidul Regency

\begin{tabular}{|l|l|l|l|l|l|}
\hline & 2010 & 2011 & 2012 & 2013 & 2014 \\
\hline $\begin{array}{l}\text { Number } \\
\text { of visits }\end{array}$ & 548,857 & 616,696 & $1,000,387$ & $1,337,438$ & $1,955,817$ \\
\hline $\begin{array}{l}\text { Direct } \\
\text { income } \\
\text { from } \\
\text { retributio } \\
n\end{array}$ & $1,717,973,70$ & $2,186,912,57$ & $3,932,090,84$ & $6,118,756,60$ & $\begin{array}{l}15,420,475,42 \\
7\end{array}$ \\
\hline
\end{tabular}


Source: Office of Culture and Tourism of Gunung Kidul Regency in Kedaulatan Rakyat, January 14, 2015:3).

Each of attraction component in Bleberan tourist village has values of something to see, something to buy, something to do and something to learn. All attractions management including its marketing are carried out by an organization within the village.

Bleberan village is situated in Playen sub-district of Gunung Kidul Regency, some 45 kilometers from the city center of Yogyakarta.

Topographically the village is dominated by karst mountain range with some spring found around the area. The spring is the source for Sri Gethuk waterfall. It is also found a cave called Rancang Kencana cave, where visitoirs can find a tree growing inside it. The community are mainly farmers or agricultural community, where some rituals are still practice such as nyadran and kenduri rasulan. Traditional foods are also found here such as pletik rice, grasshopper sambal, and cassava leaves gudeg $^{l}$.

The problems studied in this paper are:
a. What are components of attractions of Bleberan tourist village?
b. How is the management of its tourism products?
c. How is its marketing?

\section{Literature Review}

In accordance with the research questions, namely on the products and their management, the theory that would be applied also corresponds to them. They are: types of tourism, tourist village, types of tourism products, and tourism product management.

Types of tourism can be categorized based on its attractions. Based on this view, there are three types of tourism: nature based tourism, cultural tourism, and special interest tourism (cf. Pendit, 1994:71-73). Nature-based tourism is a type of tourism with nature as its main attraction, while cultural tourism is a type of tourism with culture as its main attractions. Special interest tourism, like those of

\footnotetext{
${ }^{1} \mathrm{http}: / /$ travel.kompas.com
} 
nature and culture tourism, is type of tourism based its attraction on special interests of the visitors or tourist (cf. Weiler \& Hall, 1992:5).

Meanwhile, a tourist village is an integral form of attractions, accommodation and supporting facilities presented in a community living structure that are bound together with their customs and traditions (Nuryanti 1993:2-3 in Santosa et al., 2011:57). This type of tourism is an integration of all village resources as attractions combined with supporting facilities. Meanwhile, Pitana $(1999)^{2}$ explains that a tourist village a rural area with its pristine atmosphere and environment including: structure, landscape, architecture and social pattern shaping the lives of the community that are provided in order to fulfill the need of the visitors.

Tourism product is everything including goods, services, attractions or other supporting facilities offered or sold to tourists or market to get their attention (something to see), to be owned used or consumed (something to buy) that can satisfy the need of the tourists (Mak, 2004:8 cf. Ngafenan, 1991:222-223; Kotler et al., 2002:14). Product line is goods or services offered by companies (including tourist village), whether it is single or varied products (Kodhyat \& Ramaini, 1992:90).

Tourism attraction is everything which has uniqueness, beauty and values in forms of cultural diversity and human creativity as the object of travel (Act No. 10/2000 on Tourism Chapter 1 article 5). Attraction component is each of tourism attraction element inherent in its uniqueness, beuty and values on a tourism product being used as an object for travel (Marsono, 2011:8).

Management is an analysis of planning, organizing and implementing raw materials to be a final product to be sold in order to achieve organization's goals (cf. Kotler et al., 2002:12; Marsono \& Wirjono, 2015:13). Tourism village in this case is such organization.

\section{Tourism Products of Bleberan Tourist Village and their Attarction Component Analysis}

The product of Bleberan tourist village covers both natural and cultural attractions. Both of them can be divided into two: primary and secondary

\footnotetext{
${ }^{2}$ http://coretanpetualang.wordpress.com
} 
attractions. The primary natural attractions are: Rancang Kencono cave and Sri Gethuk waterfall. The primary cultural attraction is traditional culinary including: sega pletik, sambal walang (grasshopper sambal) and sayur lodeh lombok ijo. Secondary attractions are natural attractions such as Oyo river trekking, Bleberan natural trekking; and cultural such as bersih desa/rasulan, nyadran, kenduri robyong, soy milk, art performance (doger, reog, hadroh, slawatan and jathilan), heritage site; both culture and nature: living in Bleberan village (Harjono, 12 December 2014). Analysis will be on the primary natural and cultural attractions as described in the followings:

\section{a. The Beauty of Rancang Kencono Cave and Its Attraction Component Analysis}

\begin{tabular}{|c|l|l|c|}
\hline \multicolumn{4}{|c|}{ The Beauty of Rancang Kencono Cave } \\
\hline No & \multicolumn{1}{|c|}{ Element } & \multicolumn{1}{|c|}{ Remark } & Attraction \\
\hline 1 & The name of "Rancang & $\begin{array}{l}\text { a. Etymology } \\
\text { b. History }\end{array}$ & + \\
\hline 2 & Cave entrance & Wide and bright & + \\
\hline 3 & Tree inside the cave & $\begin{array}{l}\text { a. Diameter of 1.5 m } \\
\text { b. Hundred years of age } \\
\text { c. High } \\
\text { d. Right in front of the cave } \\
\text { entrance }\end{array}$ & + \\
\hline 4 & $\begin{array}{l}\text { Stalactite and } \\
\text { stalagmite }\end{array}$ & $\begin{array}{l}\text { a. Beautiful dripstone } \\
\text { b. Lie in the cave floor }\end{array}$ & + \\
\hline 5 & Cave interrior & $\begin{array}{l}\text { a. Upper part } \\
\text { b. Middle part } \\
\text { c. Wide interior that can contain } \\
\text { up to 200 people } \\
\text { d. Dark } \\
\text { e. Bright when lighted }\end{array}$ & + \\
\hline 6 & Legend & $\begin{array}{l}\text { The place to plan for battle against } \\
\text { the Dutch (in the era of Mataram } \\
\text { and the War of Java/Prince } \\
\text { Diponegoro }\end{array}$ & + \\
\hline 7 & $\begin{array}{l}\text { Chamber inside the } \\
\text { cave }\end{array}$ & $\begin{array}{l}\text { a. Used as a place for meditation } \\
\text { b. Quiet and dark }\end{array}$ & + \\
\hline 8 & Entrance ticket & Rp 7,000 & + \\
\hline
\end{tabular}




\section{- Pictures of Rancang Kencono Cave}
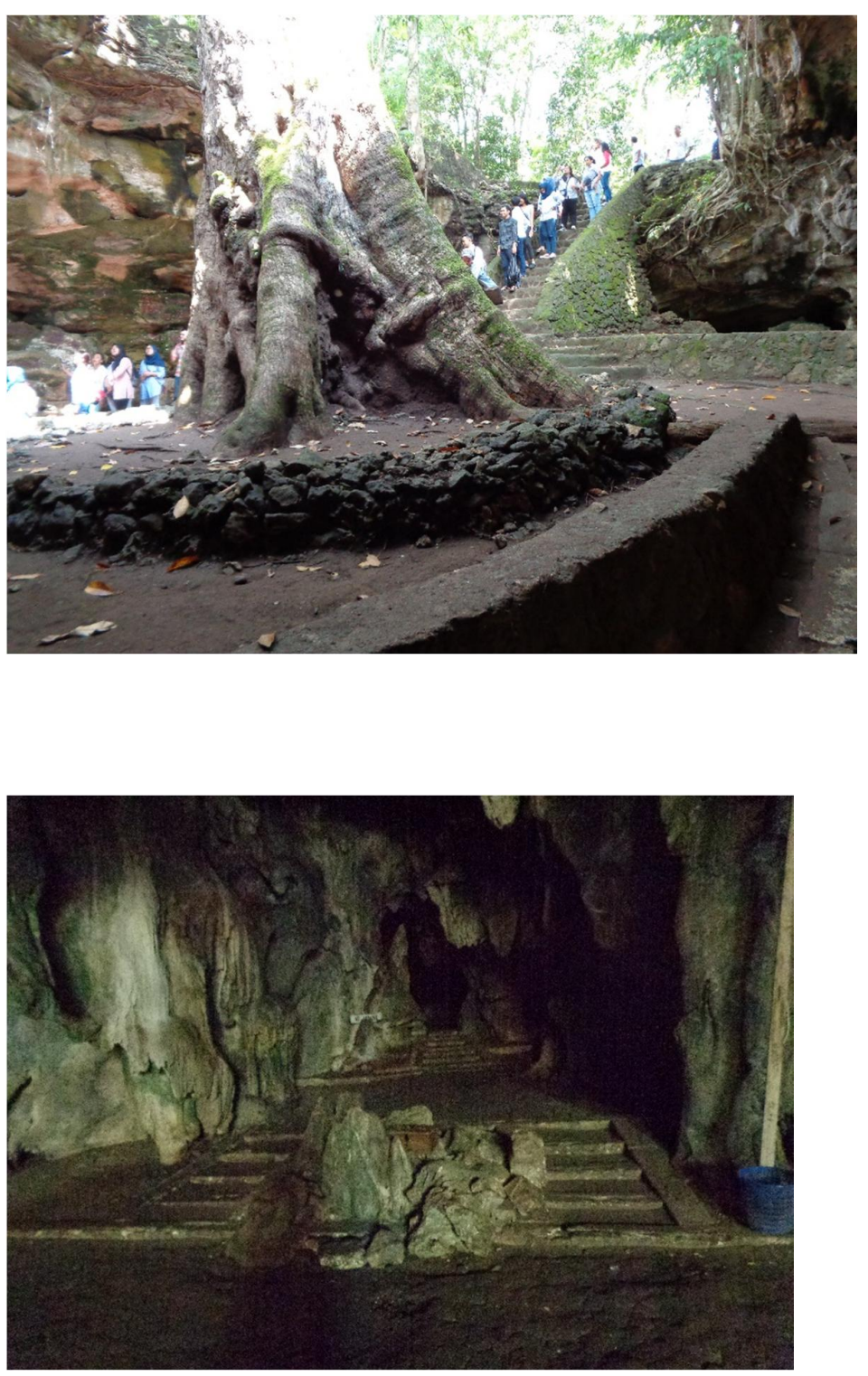

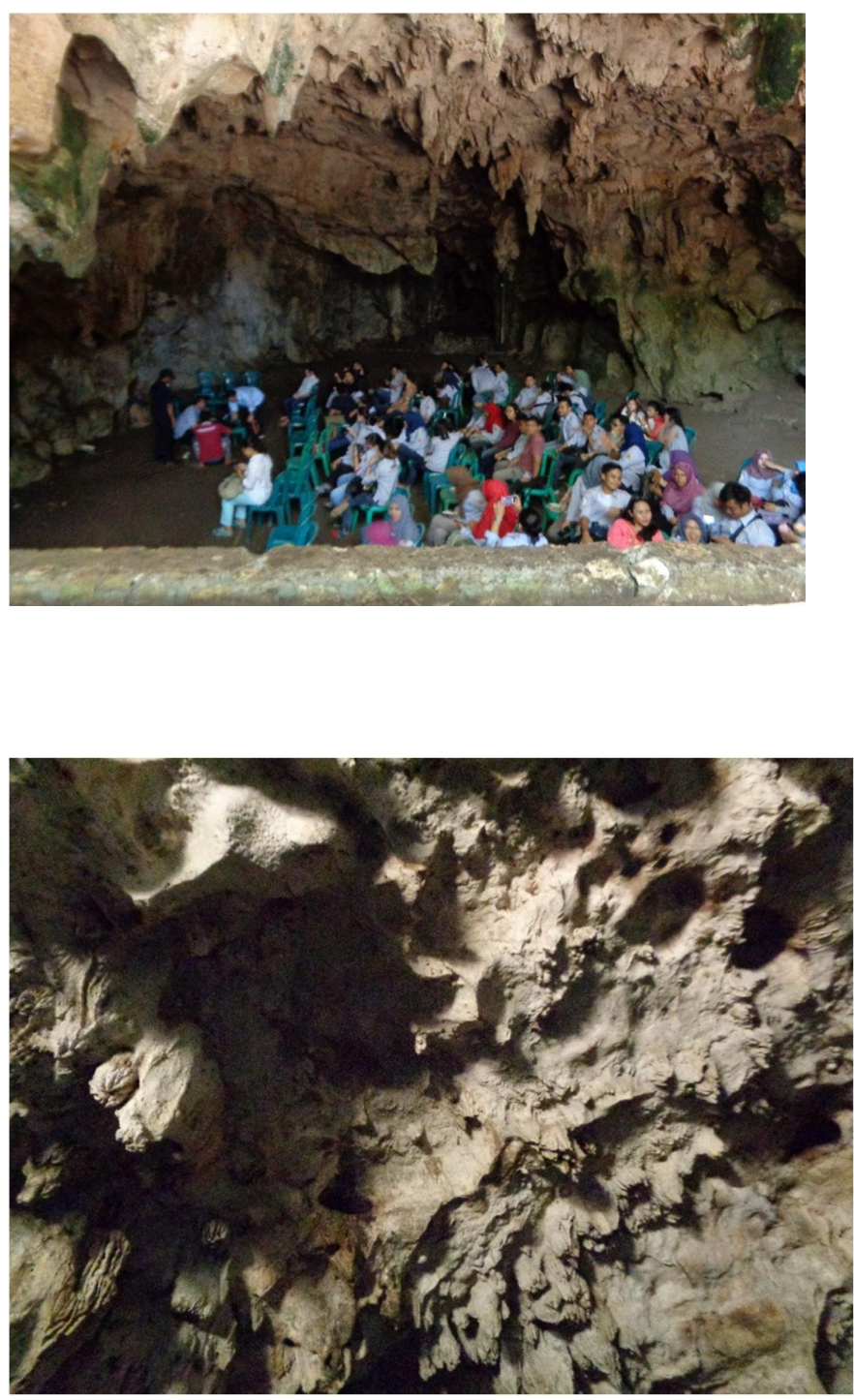

b. The Beauty of Sri Gethuk Waterfall and Its Attraction Component Analysis

\begin{tabular}{|c|l|l|c|}
\hline \multicolumn{4}{|c|}{ The Beauty of Sri Gethuk Waterfall } \\
\hline No & \multicolumn{1}{|c|}{ Element } & \multicolumn{1}{c|}{ Remark } & Attraction \\
\hline 1 & $\begin{array}{l}\text { The peak of the } \\
\text { waterfall }\end{array}$ & $\begin{array}{l}\text { a. 50 meter high } \\
\text { b. White in color } \\
\text { c. The origin of the spring }\end{array}$ & + \\
\hline 2 & $\begin{array}{l}\text { The middle area of the } \\
\text { waterfall }\end{array}$ & $\begin{array}{l}\text { a. The speed of the water falling } \\
\text { b. The sound and color of the } \\
\text { water falling (white) }\end{array}$ & + \\
\hline 3 & $\begin{array}{l}\text { The below area of the } \\
\text { waterfall }\end{array}$ & $\begin{array}{l}\text { a. Karst area } \\
\text { b. Elevation almost 90 degrees } \\
\text { c. Bushes around the base }\end{array}$ & + \\
\hline
\end{tabular}




\begin{tabular}{|c|c|c|c|}
\hline 4 & Waterfall base & $\begin{array}{l}\text { a. Karst area } \\
\text { b. Bushes around the base } \\
\text { c. Full of water } \\
\text { d. Slippery } \\
\text { e. Photography spot area } \\
\end{array}$ & + \\
\hline 5 & Oyo River area & $\begin{array}{l}\text { a. Raft terminal } \\
\text { b. Oyo River scenery } \\
\text { c. Swimming area }\end{array}$ & + \\
\hline 6 & $\begin{array}{l}\text { The situation of the } \\
\text { waterfall }\end{array}$ & $\begin{array}{l}\text { a. Clean water scenery } \\
\text { b. Water volume reaching up to } \\
501 \mathrm{~mm} \text { per second } \\
\text { c. Never experience drought } \\
\text { d. Elevation almost } 90 \text { degrees }\end{array}$ & + \\
\hline
\end{tabular}

\section{- Pictures of Sri Gethuk Waterfall}

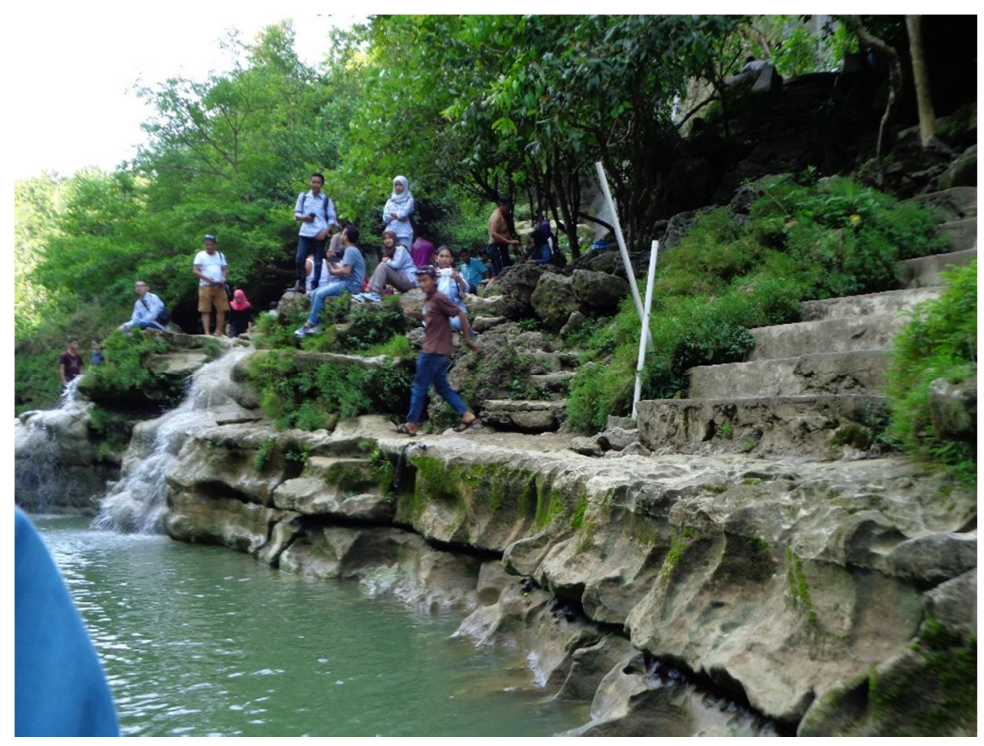



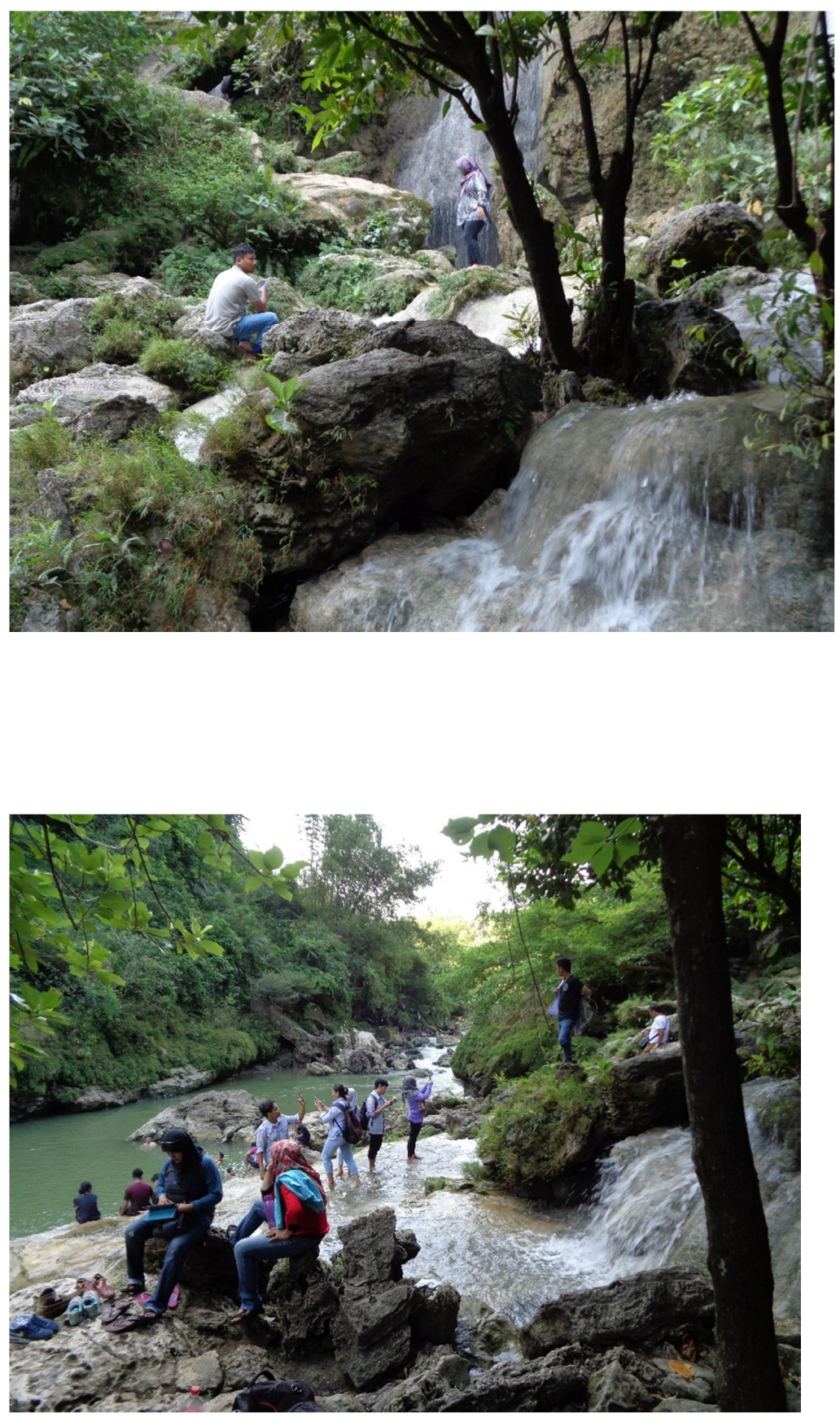

c. The Beauty of Rafting in Sri Gethuk Waterfall and Its Attraction Component Analysis

\begin{tabular}{|c|l|l|c|}
\hline \multicolumn{4}{|c|}{ The Beauty of Rafting in Sri Gethuk Waterfall } \\
\hline No & \multicolumn{1}{|c|}{ Element } & \multicolumn{1}{|c|}{ Remark } & Attraction \\
\hline 1 & $\begin{array}{l}\text { Walking to the raft } \\
\text { terminal (about } 400 \\
\text { meters from the parking } \\
\text { lot) }\end{array}$ & $\begin{array}{l}\text { a. } \\
\text { bood stalls and souvenir shops } \\
\text { brea available along the path } \\
\text { Trees grow along the path to the } \\
\text { terminal }\end{array}$ & + \\
\hline
\end{tabular}




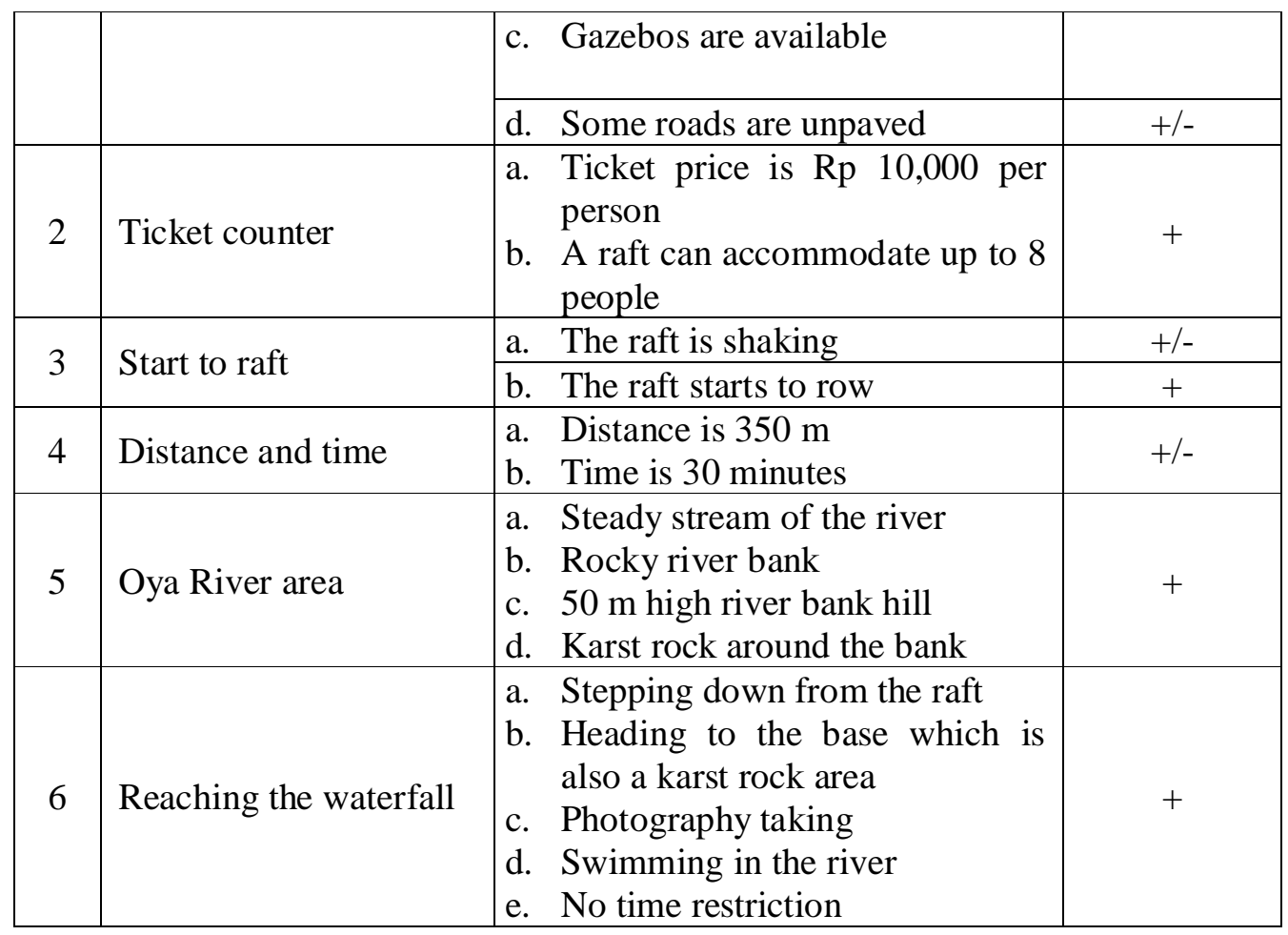

- Pictures of Rafting in Sri Gethuk Waterfall

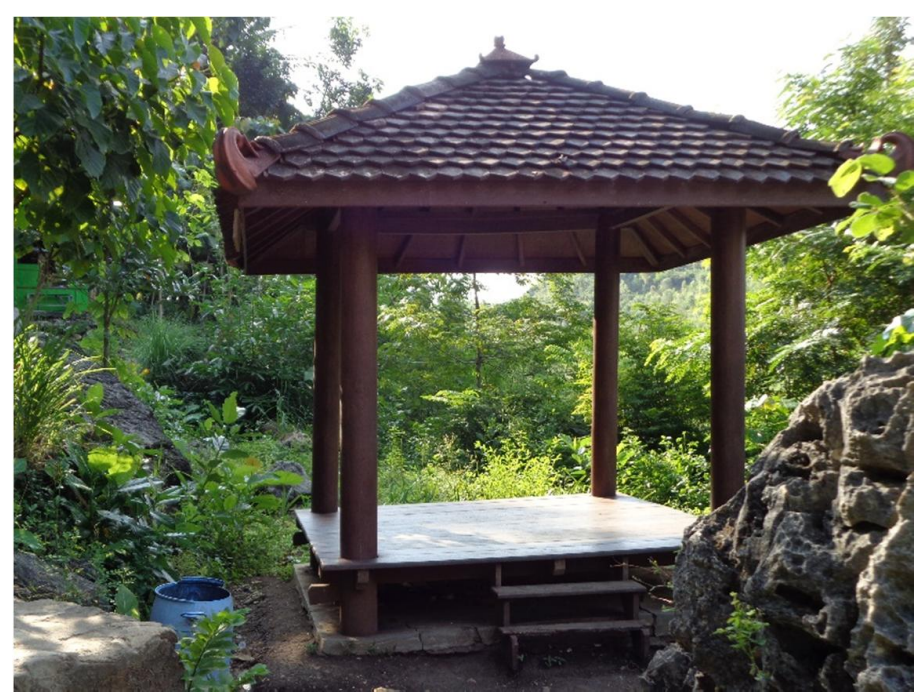



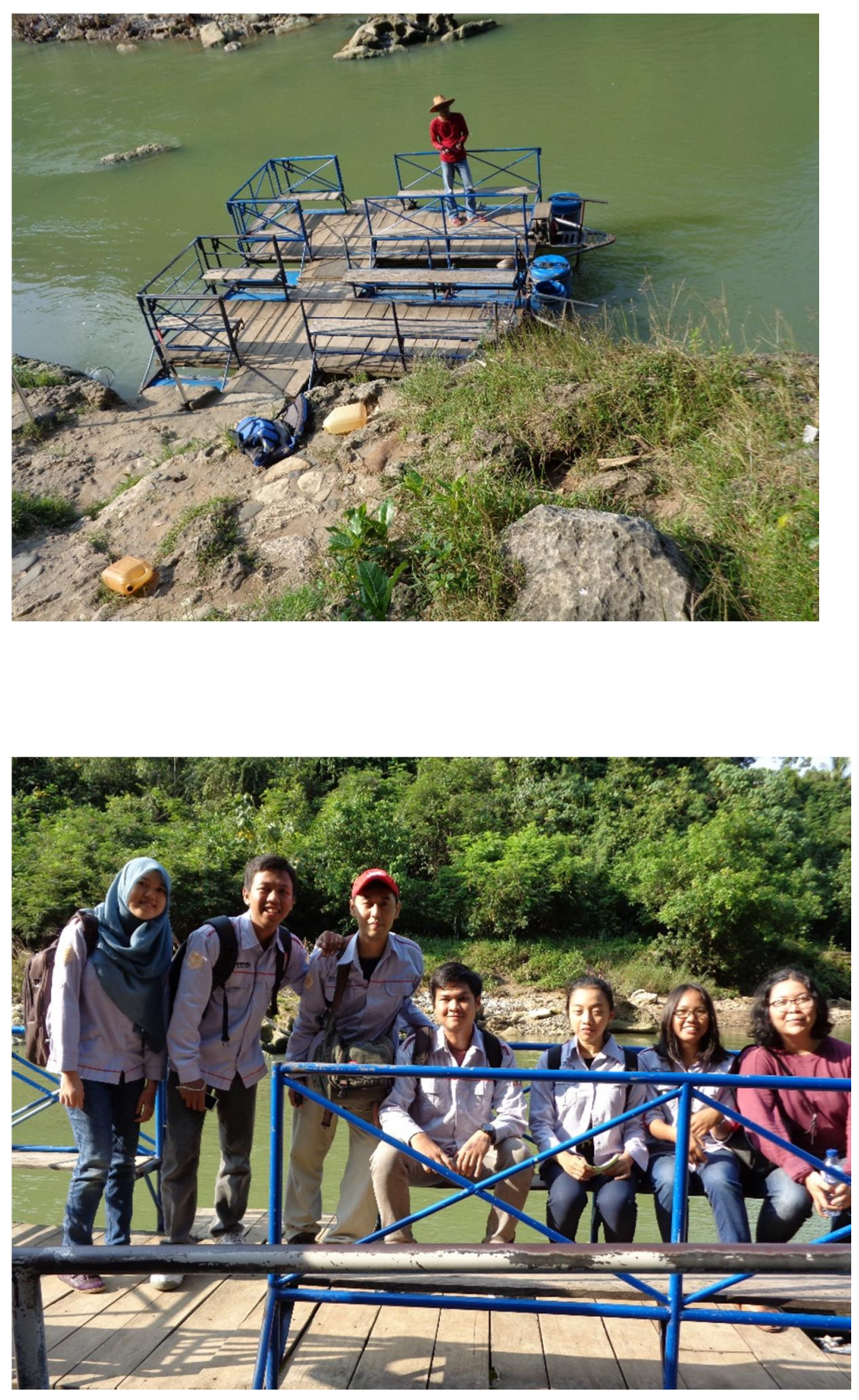

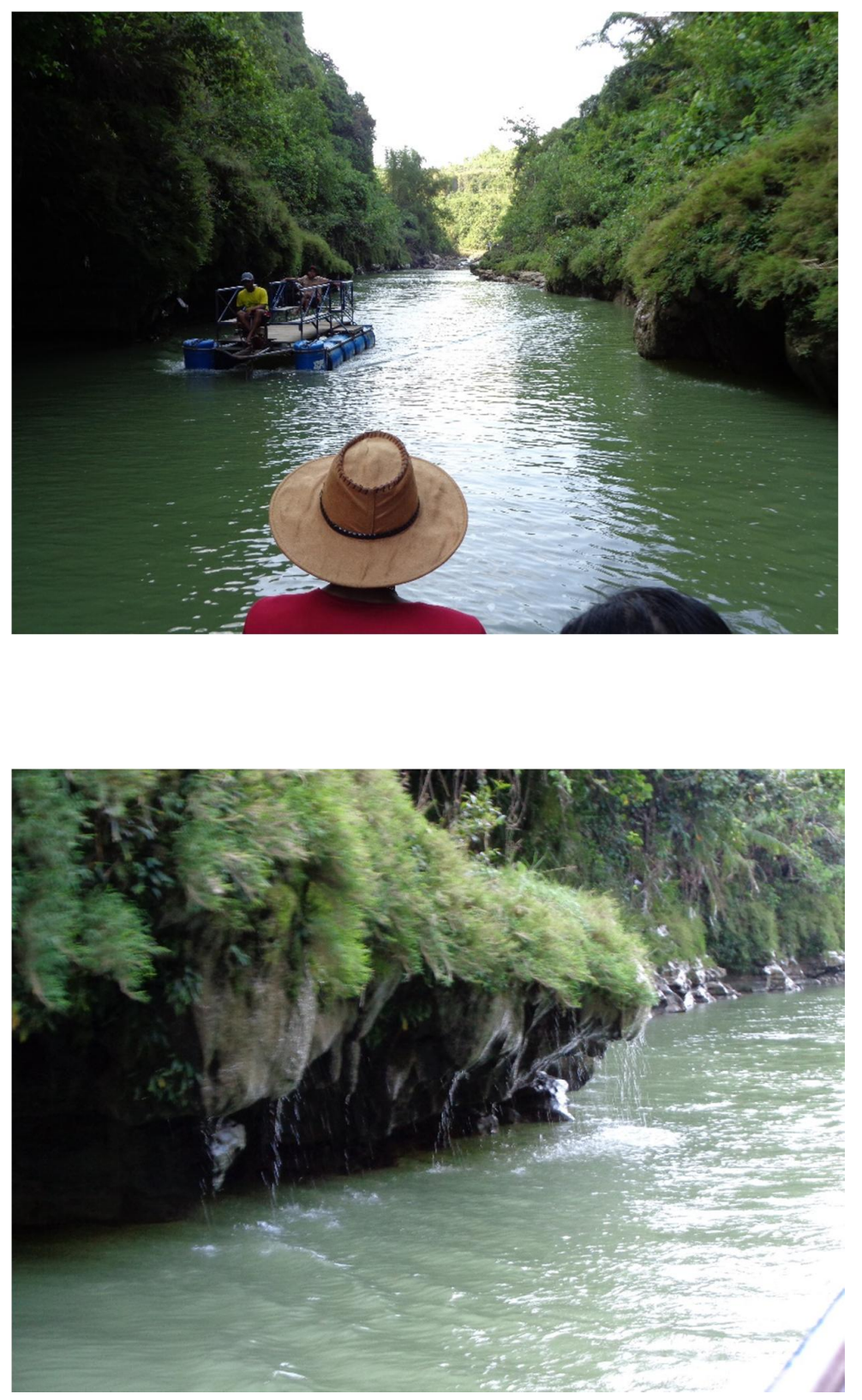

d. Traditional Food and Its Attraction Component Analysis

\begin{tabular}{|c|c|c|c|}
\hline \multicolumn{4}{|c|}{ Traditional Food and Its Attraction Component Analysis } \\
\hline No & Element & Remark & Attraction \\
\hline 1 & Nasi pletik & $\begin{array}{l}\text { a. Rice } 30 \% \\
\text { b. Cassava rice }(t i w u l) 30 \% \\
\text { c. Main food for local people } \\
\text { during the famine }\end{array}$ & + \\
\hline 2 & Grasshopper sambal & $\begin{array}{ll}\text { a. } & \text { Fried grasshopper } \\
\text { b. } & \text { Chili paper } \\
\text { c. Onion } \\
\text { d. } & \text { Garlic }\end{array}$ & + \\
\hline
\end{tabular}




\begin{tabular}{|c|c|c|c|}
\hline & & e. Salt & \\
\hline 3 & Sayur lodeh lombok ijo & $\begin{array}{ll}\text { a. } & \text { Tempeh } \\
\text { b. } & \text { Green chili paper } \\
\text { c. } & \text { Coconut milk } \\
\text { d. } & \text { Onion } \\
\text { e. } & \text { Garlic } \\
\text { f. } & \text { Salt } \\
\text { g. } & \text { Bay leaves } \\
\text { h. } & \text { Galangal } \\
\end{array}$ & + \\
\hline 4 & Cassava leaves gudeg & $\begin{array}{ll}\text { a. } & \text { Young jack fruit } \\
\text { b. } & \text { Cassava leaves } \\
\text { c. } & \text { Coconut milk } \\
\text { d. } & \text { Salt } \\
\text { e. } & \text { Sugar } \\
\end{array}$ & + \\
\hline 5 & Gudangan & $\begin{array}{ll}\text { a. } & \text { Spinach } \\
\text { b. } & \text { Kale } \\
\text { c. } & \text { Lettuce } \\
\text { d. } & \text { Grate of carrot } \\
\text { e. } & \text { Long bean } \\
\text { f. } & \text { Sprouts } \\
\text { g. } & \text { Grated coconut } \\
\text { h. } & \text { Salt }\end{array}$ & + \\
\hline 6 & $\begin{array}{l}\text { Tempeh and tofu } \\
\text { bacem }\end{array}$ & Tempe and tofu cooked in bacem & + \\
\hline 7 & Rambak crackers & Crackers made from rice floor & + \\
\hline 8 & Fried chicken & $\begin{array}{l}\text { Fried chicken cooked in bacem } \\
\text { way at first }\end{array}$ & + \\
\hline 9 & Fruits & $\begin{array}{ll}\text { a. } & \text { Boiled banana } \\
\text { b. } & \text { watermelon }\end{array}$ & + \\
\hline 10 & Drinks & $\begin{array}{l}\text { a. Sweetened tea } \\
\text { b. water }\end{array}$ & + \\
\hline 11 & Price & $\mathrm{Rp} 25,000$ per portion & $+/-$ \\
\hline
\end{tabular}


- Pictures of Traditional Foods of Bleberan Village
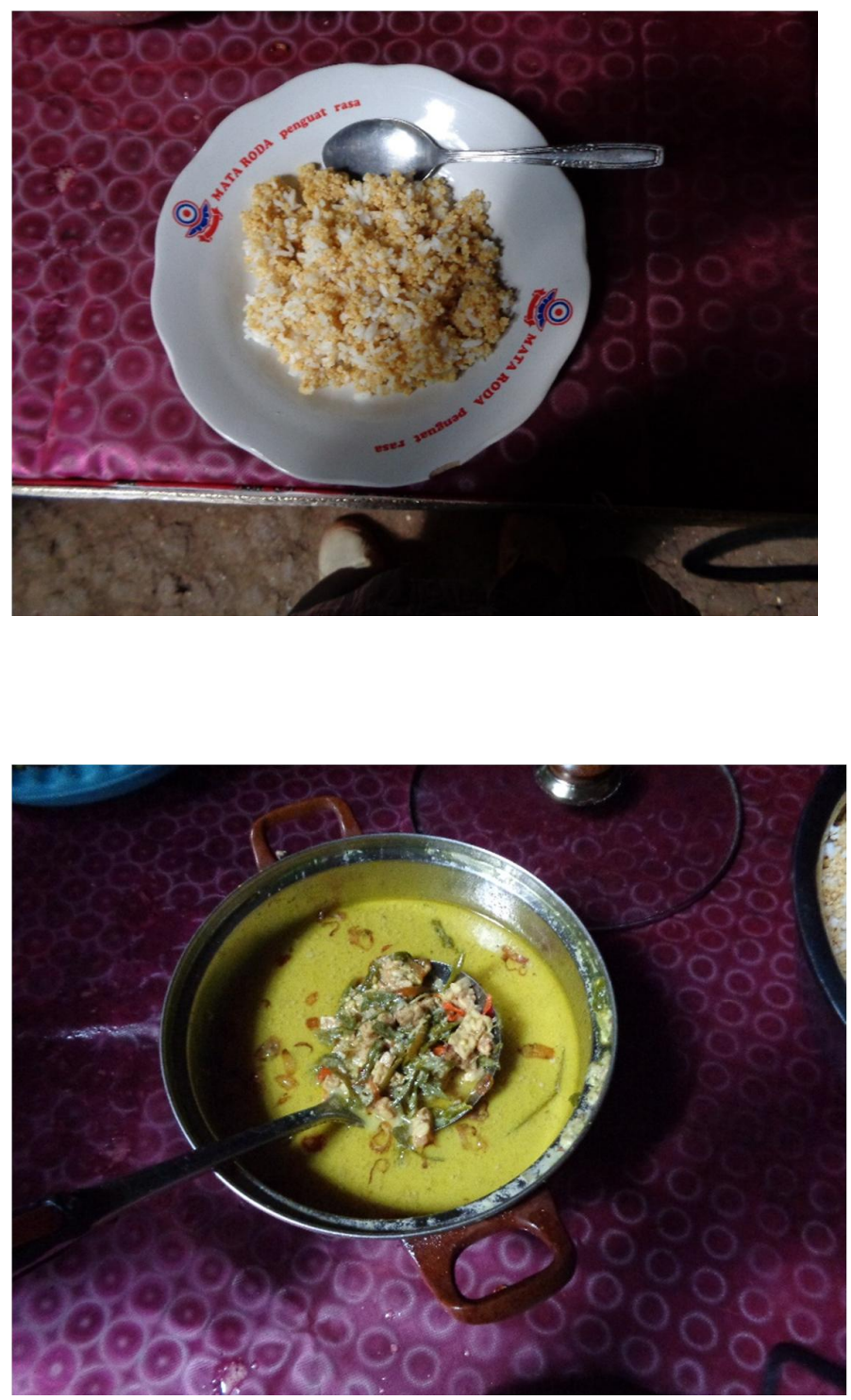

a. Traditional Snack and Its Attraction Component Analysis

\begin{tabular}{|c|l|l|c|}
\hline \multicolumn{5}{|c|}{ Traditional Snack and Its Attraction Component Analysis } \\
\hline No & \multicolumn{1}{|c|}{ Element } & \multicolumn{1}{c|}{ Remark } & Attraction \\
\hline 1 & Fried grasshopper & $\begin{array}{l}\text { a. Grasshoppers are fried } \\
\text { b. High protein } \\
\text { c. Cheap price (1 pack of Rp } \\
10,000,15,000 \text {, and 20,000) }\end{array}$ & $+/-$ \\
\hline 2 & $\begin{array}{l}\text { Thiwul (found } \\
\text { throughout Gunung } \\
\text { Kidul regency) }\end{array}$ & $\begin{array}{l}\text { a. Cassava } \\
\text { b. Skinned and dried } \\
\text { c. Pounded }\end{array}$ & $+/-$ \\
\hline
\end{tabular}




\begin{tabular}{|l|l|l|l|}
\hline & & d. & Cooked \\
e. & Served with grated coconut & \\
f. & Salt & \\
g. & Sugar (optional) \\
h. & Functioned as main food, & \\
& & & \\
\hline 3 & Resides rice & \\
Roasted young coconut & $\begin{array}{l}\text { Young coconut is roasted } \\
\text { b. Served as drink }\end{array}$ & + \\
\hline
\end{tabular}

- Pictures of Traditional Snack of Bleberan Village
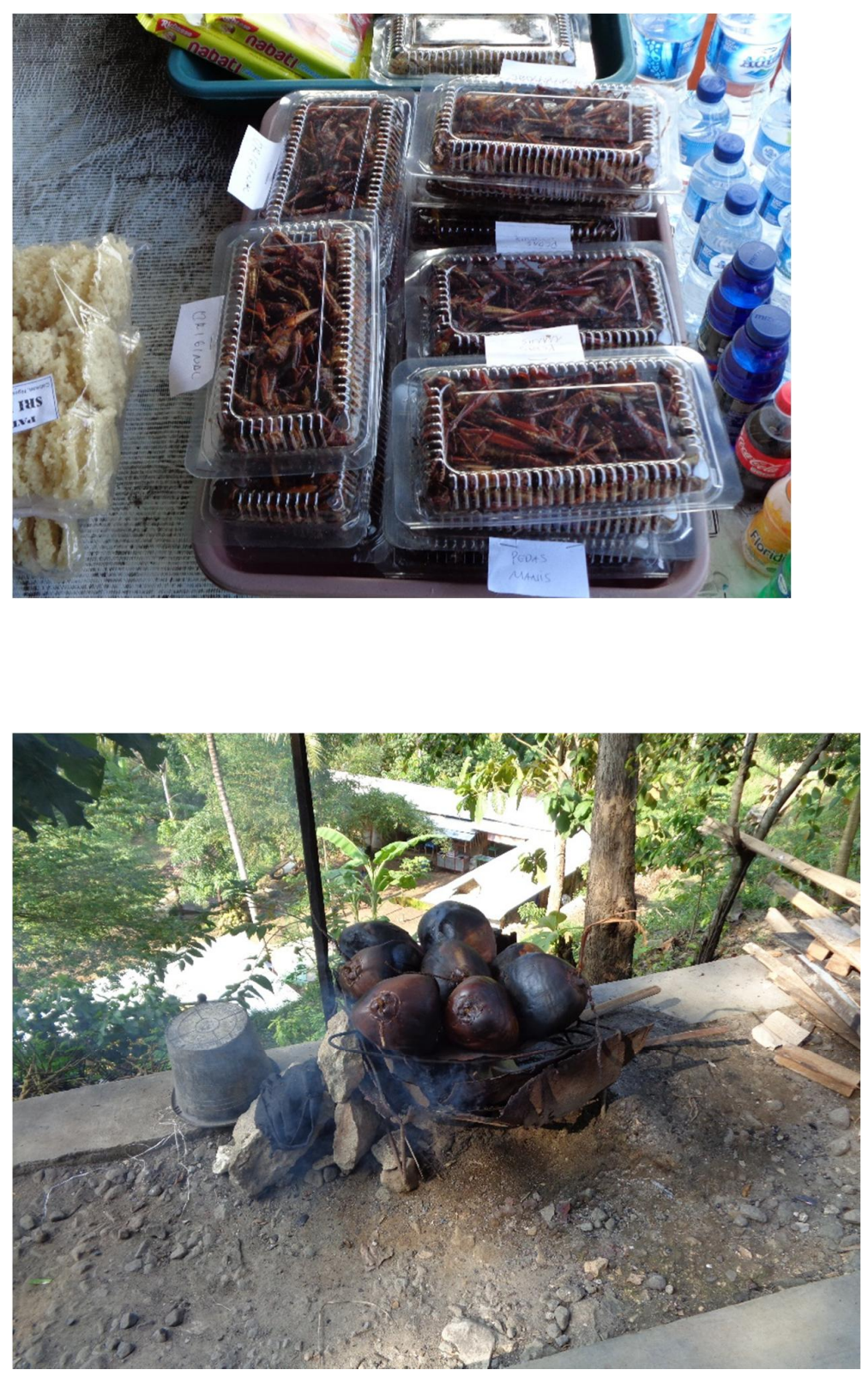


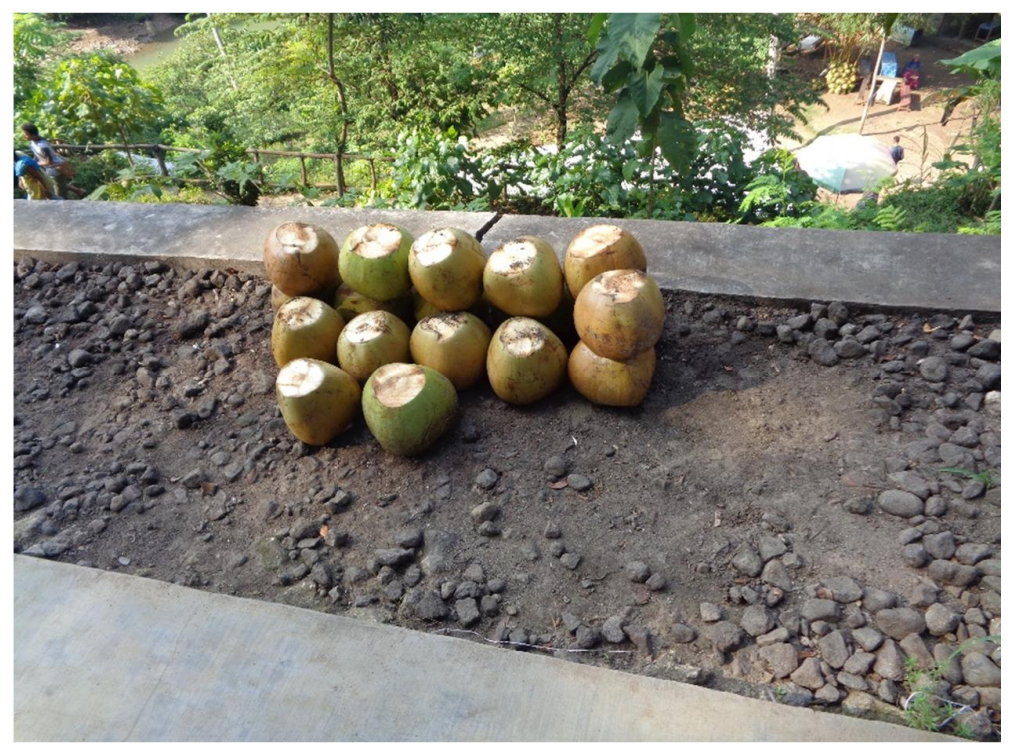

\section{The Management and Marketing of Tourism Product in Bleberan Tourist Vilage}

\section{a. The Product Management}

The management of the products offered in Bleberan tourist village is run by Tourist Village Enterprise Unit under the Village Government Owned Enterprise (BUMDes) of Bleberan village. This unit was founded in 2007, that in the beginning this institution managed only spring water for consumption of Bleberal inhabitants. There were 657 lines built in the beginning. On July 3, 2010, the Bleberan Tourist Village was launched by the BUMDes ${ }^{3}$. Organizational structure of the tourist village is ${ }^{4}$ :
a) Head : Mr. Tri Harjono
b) Secretary : 1) Mr. Susilo Hadi; 2) Mr. Syaifudin
c) Treasurer : Ms. Atik Riana
d) Divisions:

- Package and arketing: 1) Mr. M Kohar, 2) Mr. Bambang F.

- Food stall management and cleanliness: Mr. Hartono

\footnotetext{
${ }^{3}$ Based on the interview with Mr. Tri Harjono, Head of Bleberan Tourist Village on May 20, 2016 in Bleberan.

${ }^{4}$ Based on the interview with Mr. Tri Harjono, Head of Bleberan Tourist Village on March 4, 2016 in Bleberan.
} 
- Planning and development: Mr. Sumarjuni

- Rafting management: Mr. Suharno

- Parking and Security management: Mr. Purwanto

e) Tourism Awareness Group:

- Guide I: Mr. Bambang (coordinator)

- Guide II: Mr. Oki Basirudin (coordinator)

- Culinary I: Ms. Sri Sumiyarni (coordinator)

- Culinary II: Ms. Sri Rujiyati (coordinator)

- Culinary III: Ms. Umi (coordinator)

- Homestay I: Mr. Sudono (coordinator)

- Homestay II: Mr. H. Supasdi (coordinator)

\section{b. Marketing of Bleberan Tourist Village Products}

Marketing efforts of Bleberan tourist village are handled by the BUMDes through some ways, such as:

a) Printing brochures distributed to hotels in Gunung Kidul and Yogyakarta;

b) Inviting journalists from printed and electronic mass media during the launching and initiation of tourist packages;

c) Conducting travel dialogue to several provinces and cities (Jakarta, Bandung, Wonosobo, Semarang, Temanggung and Surabaya);

d) Optimizing social media such as website and Facebook.

\section{c. Number of Visits}

The aforementioned marketing and management efforts resulted in the increase of visits to Bleberan tourist village significantly since the launching in 2010. These numbers of visits from 2010 - 2015 significantly contributed to the village revenues as described in the followings ${ }^{5}$ :

\footnotetext{
${ }^{5}$ Based on the interview with Mr. Tri Harjono, Head of Bleberan Tourist Village on March 4, 2016 in Bleberan.
} 


\section{Number of Visits and Revenues in Bleberan Tourist Village $2011-2015$}

\begin{tabular}{|c|c|c|}
\hline Year & Visits & Village Revenue \\
\hline 2011 & 40,417 & $80,834,000$ \\
\hline 2012 & 103,665 & $207,330,000$ \\
\hline 2013 & 127,495 & $254,990,000$ \\
\hline 2014 & 131,259 & $262,518,000$ \\
\hline 2015 & 140,315 & $280,630,000$ \\
\hline
\end{tabular}

5. Conclusion

This study concludes that Bleberan tourist village:

a) is considered to be successful in managing its natural and cultural potentials;

b) keeps its natural and cultural environment to be developed as tourist attractions;

c) has increased village revenues due to the development of tourism, and therefore has also contributed to the people's welfare.

\section{References}

Adhisumarta, F.X. Sriyadi. 2003. "Kabupaten Gunung Kidul", dalam Profil Daerah Kabupaten dan Kota Jilid 3. Jakarta: Kompas.

Harjono, Tri. 12 Desember 2014. "Profil Lomba Desa Bleberan”.

Kedaulatan Rakyat, 14 Januari 2015:3, "Perkembangan Pariwisata di Gunung Kidul (1)”.

Kodhyat, H. \& Ramaini. 1992. Kamus Pariwisata dan Perhotelan. Jakarta: Gramedia Widiasarana Indonesia.

Kotler, Philip, John Bowen, James Makens. 2002. Pemasaran Perhotelan dan Kepariwisataan, Alih bahasa Alexander Sindoro dan Renata Poghan. Jakarta: PT Prehallindo.

Marsono. 2011. "Budaya Lokal Seni Tari Tradisi Nonkraton di DIY sebagai Daya Tarik Wisata". Laporan Penelitian Fakultas Ilbu Budaya UGM. 
2015. "Kontribusi Ekonomi ProdukWisata Gua Pindul

kepada

Masyarakat”. Laporan Penelitian Sekolah Vokasi UGM

Mak, James. 2004. Tourism and the Economics. Honolulu" University of Hawai' 1 Press.

Ngafenan, Mohamad. 1991. Kamus Pariwisata. Semarang: Dahara Prize.

Pendit, Nyoman S. 1994. Ilmu Pariwisata Sebuah pengantar. Jakarta: PT Pradnya Paramita.

Santosa, Ardi Suryawinanta, Ali Hasan, Angela Ariani, dan Nuharani EK. 2011. "Analisis Dampak Sosial dan Ekonomi Masyarakat Desa Wisata Kecamatan

Turi Kabupaten Sleman” dalam Jurnal Tourisma, No. 4/Edisi Januari 2011.

“Undang-undang RI Nomor 10 Th. 2000 Tentang Kepariwisataan”: Bab I, Pasal 5.

Weiler, Betty and Colin Michael Hall. 1992. Special Intertest Tourism. Great Britain: Belhaven Press.

Online Sources

http://coretanpetualang.wordpress.com 